\title{
PEMANFAATAN MEDIA BERMAIN ULAR TANGGA DALAM PENGEMBANGAN BERHITUNG PADA KELOMPOK A TK TUNAS MEKAR SURABAYA
}

\author{
Aulia Insani \\ PG-PAUD, Universitas PGRI Adi Buana Surabaya \\ aulia291@unipasby.ac.id
}

\begin{abstract}
This research was conducted against the background of underdeveloped children's ability to count numbers 1-20. The purpose of this study is to get a picture of the use of snakes and ladders media in developing the ability to count numbers and understand the function of playing instruments used as media in learning with play activities. Play is the most influential factor in children's self development, one of which is cognitive development. In this activity the method used is giving tasks and direct practice with observation as an assessment tool. The subjects of the study were all students of group A Tunas Mekar Kindergarten in Surabaya in the academic year 2019-2020 with a total of 20 participants. The results of the descriptive analysis revealed: The ability to count numbers before using the media was not optimal, in the assessment scores achieved from each indicator of completeness learning below the average, while using the media snakes and ladders experienced a very optimal development in the assessment scores achieved from each indicator of mastery learning very well.
\end{abstract}

Keywords: Media, Playing snakes and ladders, Counting

\section{PENDAHULUAN}

Anak adalah individu yang mengalami masa keemasan dimana perkembangan anak berkembang cepat, peasat serta mendasar untuk kehidupannya., masa ini paling berharga dan merupakan masa pembentukan, karena semua aspek perkembangan anak berkembang optimal di masa itu.. Salah satu strategi yang tepat untuk mestimulasi seluruh aspek perkembangan anak yaitu bermain. Dengan bermain, anak dapat belajar mengenali diri sendiri dan dunia dengan mengeksplorasi dan mengamati berbagai sesuatu. Stork and Sanders (2008:199) juga menyatakan bahwa "play is important of early childhood education physical activity. It is essential to development because it contributes to the cognitive, physical, social, and emotional well being of children and youth". Hasil penelitian dari The Smithsonian Institute, menjelaskan dalam Pendidikan Anak Usia Dini (PAUD) 
pembelajaran yang efektif bila melalui pembelajaran secara langsung dan berorientasi melalui permainan (Yus, 2014:46). Menurut Early Years Foundation Stage (dalam Beckley 2018:127) menyatakan bahwa bermain mendukung semua perkembangan dan belajar bagi anak.

PAUD merupakan jenjang pendidikan yang kegitan belajarnya adalah bermain. Hal ini sesuai dengan tujuan PAUD yang memilili fungsi bermain. Munurut Sujiono (2009:47) menyatakan bahwa manafaat bermain adalah memberi kesempatan pada anak untuk belajar mengeksplorasi dunia dan membangun pengetahuannya.

Bermain pada anak usia dini merupakan media yang tidak dapat dipisahkan, oleh karena itu bermain merupakan sarana sosialisasi yang diharapkan anak-anak dapat menemukan hal baru, mengekspresikan perasaan, mengeskplorasi, berkreasi dan belajar dengan nyaman serta menyenangkan. Peran media dalam dunia PAUD adalah sebagai sumber pengalaman belajar yang lebih konkret dan langsung, Karena pada masa ini anak usia dini masih berada fase berpikir konkret dan langsung. Artinya anak usia dini belum mampu berpikir diluar batas kemampuan inderanya dan masih mempelajari sesuatu dengan nyata. Media merupakan sarana komunikasi. Menurut Zaman dan Hernawan (2014:32) mengemukakan bahwa media pembelajaran adalah wadah menyalurkan pesan. Proses kegiatan belajar merupakan proses komunikasi. Melalui proses komunikasi, guru sebaiknya bertindak sebagai komunikator yang bertugas menyampaikan suatu pesan dalam kegiatan pembelajaran. Peran media sebagai komunikasi sangatlah penting dalam proses kegiatan pembelajaran di PAUD, karena media di PAUD sebagai penyampaian pesan dari guru ke peserat didik sehingga informasi dapat diterima anak secara optimal.

Bermain merupakan faktor yang berpengaruh dalam perkembangan anak, salah satunya adalah perkembangan kognitif. Dalam perkembangan kognitif, anak diberikan pemahaman tentang pra matematik antara lain mengenal konsep bilangan, berhitung, mengenal warna, bentuk, ukuran dan pola. Pada umumnya pengenalan berhitung pada anak usia dini tidak melalui bermain secara langsung, di mana guru aktif dan murid pasif.

Penulis menerangkan bahwa pengenalan berhitung pada anak usia dini sangatlah berarti sebagai 
dasar utama anak dalam mempelajari ilmu matematika pada tingkat selanjutnya dikemudian hari. Dalam pengenalan berhitung ini peneliti mengemukakan dengan cara-cara yang menyenangkan dan mudah untuk dipelajari. Dalam hal ini guru memberikan suatu pembelajaran pada anak melalui bermain yang dapat mengembangkan kognitif anak seperti media bermain ular tangga

Permaianan dengan media ular tangga adalah permainan yang dapat memberikan motivasi atau dorongan belajar kepada anak sehingga anak dapat melakukan kegiatan belajar lebih menyenangkan bagi anak dengan menghitung kotak-kotak pada papan dan dengan melempar mata dadu terlebih dahulu. Berdasarkan uraian diatas, penulis mengambil judul: "Pemanfaatan media bermain ular tangga dalam pengembangan berhitung pada kelompok A TK Tunas Mekar Surabaya".

\section{METODE PENELITIAN}

Penelitian pemanfaatan media bermain ular tangga dalam pengembangan berhitung di TK Tunas Mekar Surabaya adalah penelitian lapangan karena merupakan penelitian yang dilakukan dengan mengumpulkan informmasu data yang diperoleh langsung dari responden dan

diamati secara langsung berdasarkan pendekatan kualitatif. Penggambaran situasi pembelajaran dalam penelitan ini dengan pendekatan kualitatif. Menurut Arikunto (2010:20) adalah merupakan penelitian yang dimulai dari lapangan dengan metode induktif secara groundend, penelitiannya berkualitas, data yang dikumpulkan lengkap. Design penelitian ini yaitu one shot case study, dimana one shot case study merupakan penelitian dari suatu kelompok yang diberi perlakuan serta menggunakan satu kali pengumpulan data.

Jenis data yang di kumpulkan guna di olah dalam analisis adalah data kualitatif yaitu data yang tidak berbentuk angka atau berbentuk pernyataan, informasi, kalimat yang mendukung kelengkapan penelitian. Jenis data yang ada dalam penelitian ini terdiri dari Rencana Pelaksanaan Pembelajaran Harian (RPPH) dan proses belajar mengajar.

Keduanya mengacu pada indikator kemampuan berhitung yang ditentukan sebagai hasil observasi dalam pembelajaran dalam aspek pengembangan berhitung sebelum dan sesudah penggunaan media permainan ular tangga. Adapun data penelitian ini dari proses belajar mengajar melalui observasi, baik dari proses belajar mengajar I (tanpa media/alat peraga), proses belajar 
mengajar II (penggunaan media permaianan ular tangga).

Sumber data penelitian adalah peserta didik dari TK Tunas Mekar Surabaya tahun pelajaran 2019-2020 yaitu kelompok A dengan jumlah 20 anak. Teknik pengumpulan data penelitian ini melalui pengamatan sebagai teknik utama. observasi dalam bentuk check list (v). Observasi ini selanjutnya dilakukan di dalam kelas untuk mengetahui perkembangan kemampuan anak dalam berhitung dengan penggunaan media permaianan ular tangga.

\section{HASIL DAN PEMBAHASAN}

Pengambilan data dengan menggunakan metode observasi bertujuan sebagai teknik pengamatan dan pencatatan yang sistematis untuk penumpulan data tentang aktivitas dalam pembelajaran serta pemanfaatan media yang dipergunakan. Peneliti melakukan pengamatan sebanyak dua kali dalam pembelajaran pengembangan berhitung melalui RPPH, proses belajar mengajar dan penilaian perkembangan anak berhitung sebelum dan sesudah penggunaan media permainan ular tangga.

Adapun hasil penentuan tingkat penilaian tersebut dapat dilihat pada tabel hasil observasi dari keseluruhan indikator sebelum dan sesudah penggunaan media permaianan ular tangga sebagai berikut.

Tabel 1

Hasill observasi dari keseluruhan indikator sebelum dan sesudah penggunaan media permaianan ular tangga

\begin{tabular}{|c|c|c|c|c|c|c|c|c|c|}
\hline No. & Indikator & \multicolumn{4}{|c|}{ Sebelum } & \multicolumn{4}{|c|}{ Sesudah } \\
\cline { 3 - 10 } & $\mathbf{1}$ & $\mathbf{2}$ & $\mathbf{3}$ & $\mathbf{4}$ & $\mathbf{1}$ & $\mathbf{2}$ & $\mathbf{3}$ & $\mathbf{4}$ \\
\hline 1 & $\begin{array}{c}\text { Menunjuk/menyebutkan } \\
\text { lambang bilangan 1-20 }\end{array}$ & 1 & 3 & 7 & 9 & - & 1 & 4 & 15 \\
\hline 2 & $\begin{array}{c}\text { Menyebut urutan } \\
\text { bilangan 1-20 }\end{array}$ & 1 & 3 & 9 & 8 & - & 2 & 3 & 15 \\
\hline 3 & $\begin{array}{c}\text { Menyebutkan Gambar } \\
\text { dan jumlahnya }\end{array}$ & 2 & 4 & 7 & 7 & - & 1 & 3 & 16 \\
\hline
\end{tabular}

Keterangan:

1. Belum Berkembang (BB)

2. Mulai berkembang (MB)

3. Berkembang sesuai harapan (BSH)

4. Berkembang sangat baik (BSB) 
Tabel 2

\section{Porsentase hasil observasi kemampuan berhitung pada keseluruhan indikator sebelum dan sesudah menggunakan media ular tangga}

\begin{tabular}{|c|c|c|c|c|c|c|c|c|c|}
\hline \multirow[t]{2}{*}{ No } & \multirow[t]{2}{*}{ Indikator } & \multicolumn{4}{|c|}{ Sebelum } & \multicolumn{4}{|c|}{ Sesudah } \\
\hline & & 1 & 2 & 3 & 4 & 1 & 2 & 3 & 4 \\
\hline 1 & $\begin{array}{c}\text { Menunjuk/menyebut } \\
\text { kan lambang bilangan } \\
1-20\end{array}$ & $5 \%$ & $15 \%$ & $35 \%$ & $\begin{array}{l}45 \\
\%\end{array}$ & - & $5 \%$ & $20 \%$ & $75 \%$ \\
\hline 2 & $\begin{array}{l}\text { Menyebut urutan } \\
\text { bilangan 1-20 }\end{array}$ & $5 \%$ & $15 \%$ & $45 \%$ & $\begin{array}{l}40 \\
\%\end{array}$ & - & $10 \%$ & $15 \%$ & $75 \%$ \\
\hline 3 & $\begin{array}{l}\text { Menyebutkan } \\
\text { Gambar dan } \\
\text { jumlahnya }\end{array}$ & $10 \%$ & $20 \%$ & $35 \%$ & $\begin{array}{l}35 \\
\%\end{array}$ & - & $5 \%$ & $15 \%$ & $80 \%$ \\
\hline & Rata-rata & $\begin{array}{l}6,6 \\
\%\end{array}$ & $\begin{array}{l}16,6 \\
\%\end{array}$ & $\begin{array}{l}31,3 \\
\%\end{array}$ & $\begin{array}{l}40 \\
\%\end{array}$ & - & $\begin{array}{l}6,6 \\
\%\end{array}$ & $\begin{array}{l}16,6 \\
\%\end{array}$ & $\begin{array}{l}76,6 \\
\%\end{array}$ \\
\hline
\end{tabular}

Setelah melakukan pengamatan dan proses pengumpulan data, pada pembahasan ini peneliti akan menyajikan temuan yang telah diperoleh dari mulai melaksanakan proses pengumpulan data melalui subjek penelitian sampai memperoleh hasil porsentase dari masing-masing indikator.

Pada pembahasan ini peneliti menyajikan hasil dari pengamatan berhitung mulai sebelum menggunakan media sampai sesudah menggunakan media. Dengan begitu dapat diketahui porsentase masingmasing tingkat pencapaian perkembangan setiap indikator.

Hasil observasi pada indikator menunjuk/ menyebutkan lambang bilangan 1-20 menunjuk-kan bahwa sebelum menggunakan media ular tangga dari 20 peserta didik, diperoleh sebanyak 1 peserta didik atau $5 \%$ yang tidak dapat menunjuk/menyebutkan lambang bilangan 1-20 dan temasuk BB , 3 peserta didik atau 15\% MB, 7 peserta didik atau 35\% $\mathrm{BSH}$, dan 9 peserta didik atau 45\% BSB. Kemudian sesudah menggunakan media ular tangga dari 20 peserta didik, diperoleh 0 peserta didik atau $0 \%$ yang mampu nenunjuk/meyebutkan lambang bilangan 1-20 BB, 1 peserta didik atau $5 \%$ termasuk $\mathrm{MB}, 4$ peserta didik atau $20 \% \mathrm{BSH}$, dan 15 peserta didik atau $75 \%$ BSB.

Hasil observasi indikator menyebut urutan bilangan 1-20 menunjukkan sebelum menggunakan media ular tangga dari 20 peserta didik diperoleh sebanyak 1 peserta didik atau $5 \%$ yang tidak dapat menyebut urutan bilangan 1-20 termasuk BB, 3 peserta didik atau $15 \% \mathrm{MB}, 9$ peserta didik atau 
45\% BSB, dan 8 peserta didik atau $40 \%$ BSB. Kemudian, Sesudah menggunakan media ular tangga dari 20 peserta didik diperoleh sebanyak 0 peserta didik atau $0 \%$ yang mampu menyebut urutan bilangan 1-20 termasuk BB, 2 peserta didik atau $10 \%$ $\mathrm{MB}, 3$ peserta didik atau $15 \% \mathrm{BSH}$, dan 15 peserta didik atau $75 \%$ BSB. Hasil observasi pada indikator menyebutkan gambar dan jumlahnya menunjukkan bahwa sebelum menggunakan media ular tangga dari 20 peserta didik, diperoleh 2 peserta didik atau 10\% yang belum mampu menyebutkan gambar dan jumlahnya termasuk kategori BB, 4 peserta didik atau 20\% MB, 7 peserta didik merupakan $35 \%$ $\mathrm{BSH}$, dan 7 peserta didik merupakan 35\% BSB), sedangkan sesudah menggunakan media ular tangga dari 20 peserta didik, diperorleh 0 peserta didik atau $0 \%$ yang mampu menyebutkan gambar dan jumlahnya termasuk dalam katogeri $\mathrm{BB}, 1$ peserta didik atau 5\% MB, 3 peserta didik atau $15 \% \mathrm{BSH}$, dan 16 peserta didik merupakkan $80 \%$ BSB.

\section{SIMPULAN}

Hasil penelitian tentang pemanfaatan media bermain ular tangga dalam pengembangan berhitung anak kelompok A TK Tunas Mekar Surabaya dapat disimpulkan sebagai berikut.
Media

pembelajaran merupakan sesuatu yang digunakan dalam proses kegiatan belajar agar dapat merangsang pikiran, minat dan perhatian peserta didik, sehingga proses interaksi, komunikasi, edukasi antara guru dan peserta didik dapat berlangsung secara tepat guna. Melalui RPPM dan RPPH yang valid dan PBM yang efektif dengan menggunakan media permainan ular tangga sebagai media pembelajaran dalam pengembangan berhitung.

Pelaksanaan

dengan penggunaan permaianan media ular tangga melalui RPPH dengan model pembelajaran kelompok dengan sudut pengaman pada kegiatan inti yang dibagi tiga kelompok secara bergantian, bila kelompok tertentu bermain ular tangga maka kelompok yang lain mengerjakan kegiatan yang lain.

Hasil yang dicapai dalam aspek perkembangan kognitif yaitu kemampuan berhitung dengan penggunaan media permainan ular tangga mengalami pengembangan yang optimal dari seluruh indikator masing-masing tingkat pencapaian perkembangan menunjukkan peningkatan sehingga tidak ada peserta yang berada diskala rating belum berkembang.

$$
\text { Hasil }
$$

penelitian

menunjukkan kemampuan 
berhitung pada anak kelompok A sebelum menggunakan media bermain ular tangg belum optimal, hal ini dapat dibuktikan dengan skor penilaian yang dicapai dari setiap indikator ketuntasan belajar di bawah rata-rata, sedangkan dengan menggunakan media ular tangga mengalami pengembangan yang sangat optimal. Hal ini dapat dibuktikan dengan skor penilaian yang dicapai dari setiap indikator ketuntasan belajar sangat baik. Dalam hal ini penggunaan media permaianan ular tangga dalam pembelajaran lebih efektif dalam pengembangan berhitung.

\section{DAFTAR PUSTAKA .}

Arikunto, S. 2010. Prosedur Penelitian

Suatu Pendekatan Praktik. Jakarta: Rineka Cipta.

Beckley, Pat. 2018. Belajar pada Anak Usia Dini. Jakarta: PT Indeks

Stork, S. E Sanders, S. W. 2008. Physical Education in Early Childhood. Th Elementary School Journal. 108, (3), 197- 206.

Sujiono, Yuliani Nurani. 2009. Konsep Dasar Pendidikan Anak Usia Dini. Jakarta: PT Indeks

Yus, Anita. 2014. Model Pendidikan Anak Usia Dini. Jakarta: Kencana Prenada Media Grup.

Zaman, Badru 2014 Media dan Sumber Belajar TK. In: Esensi Sumber Belajar dalam Pembelajaran Anak Usia Dini. Jakarta: Universitas Terbuka. 